\title{
Correctional Protege Mentorship as an Effort of Resocialization in Class II Special Correctional Institution for Children of Kendari
}

\author{
Arifai $^{1}$, Zainuddin $^{2}$ \\ ${ }^{1}$ Faculty of Law, Universitas Muhammadiyah Kendari, Kendari, Southeast Sulawesi, 93114, Indonesia \\ ${ }^{2}$ Faculty of Law. Universitas Muslim Indonesia, Makassar, South Sulawesi, 90231, Indonesia \\ * Corresponding author: zainuddin.zainuddin@umi.ac.id

\begin{tabular}{|c|c|}
\hline Article & Abstract \\
\hline $\begin{array}{l}\begin{array}{l}\text { Keywords: } \\
\text { Correctional } \\
\text { LPKA; Proteges; } \\
\text { Resocialization }\end{array} \\
\text { Article History } \\
\text { Received: Jan 4, 2021; } \\
\text { Reviewed: Jan 8, 2021; } \\
\text { Accepted: Mar 1, 2021; } \\
\text { Published: Mar 6, 2021. } \\
\\
\text { DoI: } \\
\text { https://doi.org/10.222 } \\
\text { 19/liih.v29i1.15101 }\end{array}$ & $\begin{array}{l}\text { Mentorship for correctional proteges is basically an effort to resocialize proteges } \\
\text { when they return to society. The research constructs how the implementation of the } \\
\text { correctional protege mentorship system so that correctional protege can be well } \\
\text { received by the community. This research is empirical and is descriptive. The } \\
\text { research finding shows that the mentoring carried out by LPKA Class II } \\
\text { Kendari is personality mentorship which includes religious mentoring in the form } \\
\text { of congregational prayer guidance, religious lecture (kultum), and reading and } \\
\text { writing of the Koran. Mentoring legal awareness in the form of legal education. } \\
\text { Skills mentorship in the form of making hydroponics, making chairs from aqua } \\
\text { bottles and trash, and making handicrafts such as ashtrays and bracelets. The } \\
\text { implementation of mentorship at LPKA Class II of Kendari has not been } \\
\text { optimally carried out. This will have an adverse impact on correctional protege } \\
\text { when they reintegrate with communities that are still giving them a negative } \\
\text { stigma. }\end{array}$ \\
\hline
\end{tabular}

\section{INTRODUCTION}

Law Number 12 of 2011 with respect to the Juvenile Criminal Justice System or also called UUSPPA which happened on July 30, 2014, hosts different ramifications for specific gatherings in taking care of instances of kids who strife with the law. In UUSPPA, some new institutions are known, such as the Temporary Child Placement 
Institution (LPAS) and the Special Correctional Institution for Children (LPKA). Also, UUSPPA mandates the ministries that carry out government affairs in the legal sector to build BAPAS in districts/cities within a maximum of 5 years. Another implication of UUSPPA is that it relates to implementing regulations of the Law where the Government is required to stipulate 6 (six) Government Regulations and 2 (two) Presidential Regulations as operational regulations for UUSPPA which must be stipulated no later than 1 (one) year since UUSPPA comes into effect. This paper is intended to determine the readiness of the institutions and supporting regulations as implementing regulations for UUSPPA, which reflects the 2 years the UUSPPA comes into effect.

The Law on Juvenile Criminal Justice System (SPPA) has legally changed the paradigm in the handling of children in conflict with the law. The Juvenile Criminal Justice System is the entire process of solving cases of children in conflict with the law starting from the investigation stage to the guidance stage after serving a crime. The most basic substance in this Law is firm regulation regarding Restorative Justice and the diversion process. In principle, restorative justice (Diversion) is intended as an effort to prevent and keep children away from the judicial process, detention and imprisonment, deprivation of liberty and punishment can only be done as a last resort, and prevent stigmatization of children.

The Law on the Juvenile Criminal Justice System (UU SPPA) explicitly mandates the strategic role and function of Corrections in the juvenile criminal justice system. The strategic role of the correctional facility began to move from pre-adjudication, adjudication, to post-adjudication. The problems faced by children at the preadjudication stage, the problems faced include the lack of diversion efforts at the early stages of the criminal justice process, the absence of a special detention center for children which results in a mixture of child prisoners and adult detainees, the fulfillment of basic rights of children such as food quality, education, health standards, sanitation and so on. At the adjudication stage, the problems faced include children with minor and serious cases being processed to court and the minimum number of non-prison decisions. In the post-adjudication stage, the problems faced include, among others, occurring in several areas, the number and conditions of special prisons for children are inadequate, even children are often combined with adult prisoners, thus causing vulnerability to violations of rights as students and as children, which have not been properly fulfilled the rights of correctional students such as quality of food, education, health standards, worship, recreation, visits, and others (Aprilianda, 2014).

The implementation of mentorship in the correctional system will have a major effect on correctional proteges who undergo their prison terms while in prison. The correctional process that runs gradually can result in steady and mature changes for mental and physical recovery (Hamsir et al., 2019) The correctional process that runs 
gradually can result in steady and mature changes for the mental and physical recovery of correctional proteges. In the context of Islamic law, the development of correctional proteges is aimed at the realization of the objectives of Islamic law, namely or objectives that are emergency (maqashid as-Sharia), namely protecting the most important values, namely religion, soul, mind, descent, and property (Zainuddin, 2017).

The success of the correctional facility goals depends on several related parties, including officers who carry out mentorship, related agencies and the most important is the participation of the community which is expected to assist in the implementation of guidance for prisoners. The community has a very significant role in the process of re-socializing prisoners, which is currently still difficult to implement. This is because when the prisoner has finished serving his sentence and is ready to return to society, problems often arise due to the lack of readiness of the community to accept former convicts. Many people feel afraid, suspicious, and distrust in ex-prisoners who return to social life, even though ex-convicts have shown good attitudes. There are still many people who treat them unfairly. This may be one of the triggers for someone to repeat acts that violate the law. Therefore, the aspect of cooperation from various parties, especially from law enforcement and other stakeholders is a very important and crucial element in implementing the process (procedure) for child protection in Indonesia (Thalib et al., 2017).

The development of correctional protege is aimed at re-socializing and rehabilitating prisoners to become law-abiding and happy in the world and the hereafter, and preventing child prisoners from becoming recidivists. Besides, to restore social relations between correctional protege and the community, when serving a sentence, all norms prevailing in society are instilled in correctional proteges in a systematic, relevant and humane manner, without coercion and pressure. The goal is to shape the correctional students into good people after being in the community, and instill self-respect, become diligent people; obey religion, and restore spirit and mental.

There are still many people who treat them unfairly. This may be one of the triggers for someone to repeat acts that violate the law. Therefore, the aspect of cooperation from various parties, especially from law enforcers and other stakeholders is a very important and crucial element in implementing the procedure for child protection in Indonesia (Thalib et al., 2017).

The implementation of mentorship to return prisoners to a good society is essential, not only material or spiritual, but both must run in a balanced manner. These are the main things that support prisoners to easily live their lives after completing their criminal period. Mentorship from officers is expected to be able to shape the personality and mentality of prisoners who are considered bad in the eyes of society to change towards normal and under applicable norms and laws (Ningtyas 
et al., 2013) The problem often faced by children when returning to society is they are not well accepted. Therefore, the role of LPKA is to provide positive support during training in LPKA. Several measures that can be done to assist child prisoners in reintegration into the family and community must be in accordance with the needs and circumstances of the child, and the choice of treatment is based on a realistic assessment of the challenges and needs of correctional proteges (Sewu et al., 2018).

Therefore, the implementation design of the protection of correctional protege in the prison system switches to a humanism development mentorship that focuses on a humanist, familial and non-violent pattern of mentoring. Establishing a harmony between LPKA officers and correctional proteges to help improve the behavior and attitudes of correctional proteges in a better direction (Suwarnatha \& Gorda, 2016)

Research conducted by Sri Murtia Ningsih et al, states that the pattern of mentoring child prisoners in Class II Kendari LPKA is divided into two, namely: personality mentorship patterns, including: a) religious awareness mentorship, b) physical mentorship, c) intellectual ability mentorship, and d) fostering legal awareness and mentorship patterns of independence. The stages of coaching child prisoners consist of 3 stages, namely: the awareness stage, the transformation stage, and the stage of increasing intellectual abilities (Ningsih et al., 2020).

The results of other studies show that factors affecting the implementation of mentoring child prisoners are serving sentences in prisons in Southeast Sulawesi Province which includes legal substance factors, law enforcement factors, facility and infrastructure factors, public awareness factors, and community cultural factors. it can be assessed that the affecting of factors in the mentoring of child prisoners has been effective (Arifai et al., 2020).

Different researches uncover that detainment yet becomes the primary alternative for forcing sanctions on children. On the off chance that the child is given another criminal authorization, the usage of the choice isn't strong on account of the inaccessibility of offices and framework, for this situation LPKA, LPAS, and LPKS from social foundations gave by the nearby government (Al-Maidah et al., 2020).

Furthermore, the results of the pre-research conducted by the author showed that around 40 percent of the children living in LPKA Class II Kendari were trapped in robbery cases. On average, they were sentenced to 1 to 2 years more. The correctional protege for robbery cases in LPKA Class II Kendari is the highest in number.

Based on the explanation above, this research focuses on the problem of developing correctional protege mentorship to re-socialize children at LPKA Class II Kendari. The importance of coaching that is carried out by LPKA Class II Kendari to correctional protege mentorship is greatly assisted in rebuilding their personality in the coaching process, therefore research is necessary. Therefore, the implementation 
of the correctional protege mentorship development system is central to improving correctional protege mentorship when they return to society. The focus of the problem in this research is how is the implementation of the correctional protege mentorship guidance system so that correctional protege mentorship can be well accepted by the community? So, the goal to be achieved is to describe the implementation of the correctional protege mentorship guidance system so that correctional protege mentorship can be well received by the community and it is hoped that recommendations for policy directives will be produced in optimizing the implementation of correctional protege mentorship development.

\section{METHOD}

The type of this study is non-doctrinal research, which is a study that uses data sources obtained directly from community activities through field research (Efendi \& Ibrahim, 2018). This research will be conducted in Kendari City. Kendari City's research location was chosen because it was based on the following considerations: First, Kendari City has a Special Development Institution for Children. Second, in Kendari City, based on the results of this research from Sri Murtia Ningsih, Muhammad Arsyad, and Ambo Upe, that the Kendari LPKA has not been optimal in providing guidance to children (Ningtyas et al., 2013). The data used in this study are primary data obtained through in-depth interviews with child prisoners and warders in LPKA. Secondary data were used as complementary, which were data collection techniques through literature studies such as books, journals, and websites. The data were then analyzed in a qualitative-descriptive way.

\section{RESULTS AND DISCUSSION}

The concept of punishment has undergone a shift, as contained in the 2008 Blueprint for the Reformation of the Correctional System Implementation (Anonymous, 2008). that philosophically, correctional is a criminal system that has moved far away from the philosophy of retributive (retaliation), deterrence (deterrence), and resocialization. In other words, punishment (punishment) is not intended to make suffering a form of retaliation, it is not intended to deter suffering, nor does it assume the convict is someone who lacks socialization. Correctional services are in line with the social reintegration philosophy which assumes that crime is a conflict between the convicted person and the community so that punishment is aimed at restoring the conflict or reuniting the convicted person with his community. (Anonymous, 2008).

Children who have legal problems or have committed criminal acts must be handled wisely and exclusively because of their vulnerability or physical, mental, or social disabilities and their management is based on four principles, specifically (a) getting a charge out of extraordinary security; (b) have openings and offices; (c) to 
empower the youngster to develop constantly; (d) to the greatest advantage of the kid (Pratiwi, 2019)

Conceptually, children in a dispute with the law according to the SPPA Law are children who struggle with the law, children who are survivors of criminal acts, and kids who are witnesses of criminal acts. Meanwhile, children in conflict with the law are children who are 12 (twelve) years old but not 18 (eighteen) years old who are suspected of having committed a criminal act.

Table. Residents of the Class II LPKA Kendari

\begin{tabular}{c|c|c}
\hline Year & Frequency & Percentage \\
\hline 2017 & 24 & $24,24 \%$ \\
2018 & 13 & $13,13 \%$ \\
2019 & 29 & $29,29 \%$ \\
2020 & 33 & $33,33 \%$ \\
\hline Total & 99 & 100,00 \\
\hline
\end{tabular}

Source: Correctional Database System (Anonim, 2020)

Results of interviews with Akbar Amnur, the Head of LPKA Class II Kendari, (interview, 3 November 2020), about 40 percent of the children living in LPKA are due to entanglement in robbery cases. On average, they were sentenced to 1 to 2 years and more. The protege from child prisoners with robbery cases in LPKA Kendari is the highest so far. Children's spiritual mentorship is carried out at the Musholla in the form of Iqra and Koran recitations. Assisted by Dai Staff, Mubaligh/ustadz/ah from prison officer and outsides such as WIBER, Nirunabi Foundation, and GenBi.

The further exploration in the field shows that the directing elements that have been completed by jails and confinement focuses are through reciting and writing AlQur'an, Friday prayer, addresses, Islamic all-inclusive schools, and Islamic occasions. Mentoring materials including aqidah or faith, Islam, and a series of lectures about morals or manners. These subjects were delivered in the mentoring activities according to the schedule made by the Head Section of Prisoners and Protege Mentorship.

Religious mentorship is very important to achieve the ten principles of correctional which has been stipulated as follows: (1) every child is recognized, respected, and protected as a rights holder, with nonnegotiable rights to protection; (2) no child is discriminated against; (3) child protection systems include prevention measures; (4) families are supported in their role as a primary caregiver; (5) societies are aware and supportive of the child's right to freedom from all forms of violence; 
(6) child protection systems ensure adequate care; (7) child protection systems have transnational and cross-border mechanisms in place; (8) the child has support and protection; (9) training on identification of risks; (10) there are safe, well-publicized, confidential and accessible reporting mechanisms in place (Wulandari, 2012). The correctional protege who are mentored in LPKA Class II Kendari can become humans who have a good mentality and morality. The integration of personality and independence mentorship can also be realized properly.

From 06.00 - 09.00 a.m., correctional protege is required to get up early to take part in morning exercise, continue with 50 push-ups, to clean the yard of the LPKA area. Every day the assisted children are given 3 meals, at 10:00 a.m., 3:00 p.m., and 7:00 p.m. The menu is more appropriate than in Kendari Class IIA Correctional Institution. 8.00 p.m. is the time for resting before bed. Usually, assisted children do not sleep immediately.

In general, both in prisons and LPKA Class II Kendari, the institutions also collaborate with outsiders in improving the quality of mentorship provided to the correctional protege. Institutions and outsiders who are invited to cooperate by correctional institutions are as follows:

1. Work Training Center (BLK)

Work Training Centers (BLKs) are places for training and competency tests, as well as certifications that involve collaboration with various institutions. It is still conducting job training programs tailored to the needs of the job market.

2. Nirunabi Foundation

The Nirunabi Foundation is a foundation that teaches spiritual mentorship programs. The mentoring program is outlined in a memorandum of understanding signed directly by the Kendari branch of the Nirunabi coordinator.

3. Wiber Community (Wadah Indonesia Berbagi)

Wiber is a community started from the Peace Creation Grant Program from the Danish Embassy in Indonesia which focuses on education and fostering citizens of the Women's Development Institution (LPP) and the Child Development Institution. (LPKA)

4. Generasi Baru Indonesia Community (GENBI)

Genbi is a community consisting of selected college protege mentorship who come from various backgrounds of disciplines and expertise, which is believed to become new energy capable of contributing to the State from various universities in a selected region as scholarship recipients. Genbi was directly under the leadership of Bank Indonesia itself.

d. Center for Public Learning Activity (PKBM)

The part of PKBM is to instruct exceptional offspring of the country since it has the authenticity of the public authority to give schooling to the individuals who can't experience formal training. 
Next, the kinds of coaching did in LPKA Class II Kendari, in particular:

\section{Strict mindfulness Mentorship}

Strict mentorship is one piece of character improvement for a remedial protege. This strict improvement intends to build the devotion of restorative protege mentorship towards God Almighty, both Muslim and non-Muslim children. The presence of strict coaching by applying strict qualities and virtues is normal that restorative protege mentorship will draw nearer to God and can understand the errors they have submitted (Sitorus, 2018).

Article 3 Paragraph (1) Government Regulation of the Republic of Indonesia Number 32 of 1999 concerning Requirements and Procedures for the Implementation of the Rights of Correctional Assistants that every prison officers must provide religious education and guidance.

The development of religious awareness is considered the earliest training that must be followed by the Correctional proteges of Class II Kendari LPKA. Guidance in this field is expected to be able to increase awareness of each other's religions and be aware of the actions they did before being placed in LPKA Class II Kendari. In order to mentoring religious awareness, correctional office and proteges collaborating in the religious aspects, or volunteers who are willing to give their time free of charge.

This mentorship is carried out by increasing religious activities. Religious activities are carried out in LPKA Class II Kendari in line with law number 12 of 1995 concerning correctional facilities which aims to foster prisoners to realize their mistakes and improve themselves so that they can go to the community and live naturally.

The method of religious guidance for correctional proteges has its own characteristics because they are a separate community group that has certain characteristics, traits, and psychological conditions. Therefore, there are several methods of religious mentorship, namely: First, the personal approach method, which is a method that is carried out by directly approaching each correctional student. The coach conducts a direct dialogue with individuals, provides explanations and solutions to problems in terms of religious appreciation; Second, the lecture method, namely the method through conveying material orally by the supervisor. Meanwhile, the role of the audience as the recipient of the message is to listen to, pay attention to and record the information conveyed by the Islamic extension agent if necessary. The use of the lecture method in religious formation must be combined with other methods such as question and answer or interactive dialogue; Third, the consultation method, which is a method that is a continuation of the lecture method. In this method, coaches provide opportunities for correctional students to ask for advice or information individually. In consultation, correctional students who come to the coach to raise their personal problems and ask for instructions to solve the 
problem; Fourth, the method of gathering, which is the method of connecting correctional proteges with their families either through letters or direct visits to the house to alleviate their suffering. Gathering (silahturahmi) is an activity to visit one person to another in order to strengthen the ties of love/brotherhood (Thohir, 2016). Third, the interview technique, which is a strategy that is a follow-up of the communication technique. In this technique, the mentor gives opportunities to a correctional protege to request counsel or data separately. In the discussion, a correctional protege goes to the guide to raising his/her problems and requests guidance to take care of the problems. Fourth. the get-together technique, which is the strategy for interfacing restorative protege with their families either through letters or direct visits to the house to lighten their torment. The social event is a movement to visit one individual to another to strengthen the bonds of fondness/fellowship (Thohir, 2016)

Most of the religious mentorship that has been done so far uses the lecture and discussion method. Even though religious counseling is routinely held, the religious counseling at LPKA Class II Kendari has not been effective in maintaining the behavior of correctional proteges. If recitation is carried out, not all correctional proteges who are Muslim are involved in the recitation and prison officers do not require correctional proteges to participate in submissions, meaning that it depends on the awareness of each them. In addition, extension officers who are presented by prison managers are often unable to answer the real problems of correctional proteges. Therefore, the religious development of correctional proteges continues to be carried out in the context of increasing their faith and devotion, so that when they return to society, they can be well accepted by the community (RA et al., 2020).

There are several reasons for the assisted residents to participate in religious activities, including wanting to increase their religious knowledge, but some are just joining in, some are because of their own will. The results of research conducted through interviews with several correctional proteges, the religious activities that has been carried out increased knowledge, so far, it was not coercion from the officers. There is a lot of knowledge gained such as being able to recite the Koran, already knowing the procedures for ablution (wudhu), procedures for prayer and that becomes a provision if the child has returned to society.

The presence of the protege in Islamic religious formation varies, most of them follow religious mentorhip. When the researcher asked the proteges of LPKA Correctional Class II Kendari about the lecture of the importance of praying on time and the importance of praying in congregation. The results of interviews with correctional proteges stated that they performed their prayers on time after being in LPKA Class II Kendari.

In general, the correctional proteges in the LPKA Prison Class II Kendari stated that their religious understanding had increased since they participated in Islamic 
religious activities. They are accustomed to and often recite the Koran after they participate in Islamic religious activities, many of them even memorize short surahs.

This religious mentorship is significant because, with the mentoring of religion, correctional proteges can be encouraged in their confidence and understanding, so they can realize the values of their activities. The Humanistic methodology through strict mentoring must have the option of exposing human quality problems and estimates of public activity in the eyes of the public. (Mursyid, 2019).

Theoretically, the most effective mentorship for correctional proteges is through a religious approach because correctional proteges are human beings who are deprived of their rights of freedom, therefore they are always afflicted with feelings of anxiety, anxiety and exhaustion which in the end give rise to despair. To encourgae their spirit to live, they need to be given religious deepening while serving their sentence (Susanti, 2017). The most important element in formation is religion. Without sufficient religious provisions, it is impossible for criminal protege to continue their life outside the Special Correctional Institution for Children. So, a criminal child must also have a religion provision in addition to skills (Cahyaningtyas, 2017).

Basically, religion played an important role in the daily life of many prisoners. For those who are locked up, a relationship with God can provide comfort during periods of isolation from their families and communities. From a policy perspective, spiritual development and religious practice promote rehabilitation and reduce recidivism in correctional proteges. (Moustafa, 2014).

The same opinion is said that mental and spiritual mentoring will not be effectively carried out if the correctional service is limited. Spiritual guidance is an inseparable part of correctional proteges as provisions when their detention period has ended. (Nugroho, 2017).

\section{Legal Awareness Mentorship}

Mentoring legal awareness for correctional protege in LPKA Class II Kendari is carried out by providing legal counseling aimed at achieving a high level of legal awareness so that as members of society, correctional protege mentorship are aware of their rights and obligations to participate in upholding law and justice, protection of human dignity, order, peace, legal certainty and the formation of the behavior of every Indonesian citizen who obeys the law. One form of activities carried out in the framework of fostering legal awareness is legal counseling which aims to form legal conscious correctional proteges who are fostered while in the mentoring environment or after returning to the community.

Lawful directing coordinated by the Regional Office of the Ministry of Law and Human Rights of Southeast Sulawesi Province is done in a vis-à-vis way, for instance through talks, lawful conversations. As per Muhammad Alfar, (Interview, November 4, 2020) as the Class II Kendari LPKA Advisor expressed that: 
“This legal counseling activity is to create better correctional protege so that each of them may realize and appreciates their rights and obligations as citizens by realizing national values in everyday life and realizing a legal culture in a conscious attitude and behavior. obey and obey the law and respect human rights."

Unfortunately, legal counseling at LPKA Class II Kendari is not routinely carried out. This legal counseling activity was given during the children's orientation. After a period of orientation and implementation, adjust to other activities. Fostering legal awareness for correctional protege in LPKA Class II Kendari is the obligation of all correctional protege, including obeying and obeying all the rules and regulations that apply in LPKA Class II Kendari.

Unfortunately, legal counseling at LPKA Class II Kendari is not routinely carried out due to budget constraints, extension personnel, facilities, and infrastructure. This legal counseling activity is provided during child orientation. After the orientation and implementation period, adjust it to other activities. Fostering legal awareness for correctional children in LPKA Class II Kendari is the obligation of all correctional protege, including obeying and obeying all the rules and regulations that apply in LPKA Class II Kendari.

Mentorship of legitimate attention to remedial protege at LPKA Class II Kendari is done by giving lawful advising which expects to accomplish a significant level of lawful mindfulness so that as a citizenry, correctional protege know about their privileges and commitments to partake in maintaining law and equity, the security of respect and human pride, request, harmony, lawful sureness and the forming of the conduct of each Indonesian resident who complies with the law. Legitimate advising further means to shape a Legal Awareness Family (Kadarkum) which is tutored while in the coaching climate and subsequent to getting back to the network (Tjahjati, 2012).

3. Skills training program

Skills development is a part of self-reliance building. Self-reliance training is provided to the children assisted by LPKA Class II Kendari through programs, namely: farming (polyback), Hydroponic, making chairs from aqua bottles and trash, making handicrafts such as ashtrays and bracelets. The existence of this training can help them so that they can mingle with their surroundings. Self-reliance development is given programs such as skills to support independent businesses, skills to support small businesses, and skills that are developed according to the talents of each correctional proteges.

To realize mentoring for correctional proteges, LPKA Class II Kendari has made various efforts that are needed. One of them is a skills training program in the field of handicrafts so that if they are free from LPKA Class II Kendari they will be equipped with skills to develop their lives in a better society. 
The skills training provided by the Class II Kendari LPKA mentoring Staff received a positive response from the assisted residents and parents or guardians of the protege, this can be seen from the seriousness of the children in participating in the training and then practicing it. Also, the children hope that these skills can be used as provisions for working in the community.

Skills development can be defined as a person's efforts to develop his / her potential, both physically and spiritually, to be able to carry out tasks, and be professional in their fields, think systematically, have high creations for a more perfect life. But the purpose of the skills in this paper is the ability of correctional students to have creations, works so that these works can be independent and have confidence in the ability to try to support themselves and their families.

According to Laode Mashudan, Class II Kendari LPKA Coaching Staff (interview, 3 November 2020), skills training for correctional students is carried out in several ways, namely: providing instructions, direction and advice, organizing general knowledge courses, vocational training such as carpentry, handicrafts. , sewing and so on, physical exercise to maintain health. As for the benefits to be obtained from the development of these skills so that correctional students can master certain skill areas, form a productive workforce, be able to work and try to earn a living with their own business in a halal, independent manner and have confidence in the ability to do business.

With the skills training carried out in the Class II Kendari LPKA, correctional protege can accept LPKA as the new home. In addition, they can introspect themselves when the correctional protege is free and can no longer make mistakes that can return the correctional protege mentorship to LPKA.

In spite of the fact that there is an expansion in the imagination of restorative protege mentorship through making painstaking work to occupy their extra time, this training has not yet been done ideally because of spending imperatives and ability offices to give crude materials to aptitudes. This expertise improvement is completed with the goal that later restorative protege re-visitation of the network to become free individuals.

Aptitudes improvement plans to develop a lot the gifts of remedial protege, to secure ability and aptitudes. The exercises completed are leading information courses (proficiency destruction), primary school balance courses, professional preparing, for example, handiworks, for example, making seats and brushes, actual preparing to keep up physical and otherworldly wellbeing, morning exercise, workmanship activities, for example, music. So when the jail term is finished, they can without much of a stretch find a new line of work as per the abilities they are occupied with LPKA (Lumowa, 2017)

The social reintegration after the restorative protege has wrapped up carrying out punishment, it is something significant to do. So it is important to furnish them 
with issues identified with improving delicate abilities to build their freedom. One type of freedom is simply the capacity to make occupations and in any event, for other people. Understanding the significance of provisioning for remedial protege in confronting life subsequent to finishing a sentence, every jail sorts out freedom training as abilities instruction. The objective is to create restorative protege with the goal that they could have legitimate abilities in the wake of being delivered while spending time in jail in jail (Bukhori, 2016)

Although the mentorship given in LPKA, aims to provide physical, mental, and social readiness to correctional proteges, they will find different things after leaving LPKA. Family support, resources in community life, and moral support from the community are important and affect the reintegration of correctional proteges in society (Arifulloh et al., 2017).

Although the mentorship is given in LPKA, there is a difference between prison and LPKA. In prison, children only receive non-formal education. Whereas in LPKA, there must be formal education such as State Primary Schools (SD) or State Junior High School (SMP). So that the assisted children can continue their schooling even though they are serving a criminal sentence so that they do not miss their formal education. Family support, resources in community life, and moral support from the community are important and affect the reintegration of correctional proteges in society (Arifulloh et al., 2017)

In every aspect of the development of correctional proteges, as a provision for resocialization to the society, LPKA, and its partners implement character-based methods (Rezaliano \& Humsona, 2018), namely: First, exemplary, in this aspect, LPKA officers and partners strive for good examples in correctional proteges such as starting activities with prayer, prioritizing honesty, and being polite. Through habituation regarding the role models of correctional proteges, efforts are made to imitate the good things in their environment. Second, spontaneous activities, this aspect are aimed at correctional proteges having the courage to start and have initiatives that can be seen in religious activities and socialization where correctional proteges are spontaneously asked to lead prayers or make self-introductions in turns. Third, reprimand, giving a warning to correctional proteges is one of the methods of character where it can be seen by the provision of rewards and punishments, such as if correctional proteges do not violate the rules, then they need for their freedom will be facilitated. Fourth, environmental conditioning. Environmental conditioning is an important element in character-based coaching, namely where supportive conditions will increase the effectiveness of mentoring. This is directly related to the fourth aspect, namely routine activities, correctional proteges are directed to participate in mandatory and routine activities so that they will slowly perceive coaching as a habit, no longer a punishment that must be endured. 


\section{CONCLUSION}

The mentorship carried out by LPKA Class II Kendari is personality development which includes religious mentorship in the form of congregational prayer coaching, religious lecture, reading, and writing of the Koran. Legal awareness mentorship was also done in the form of legal counseling for correctional proteges. This personality development is carried out to awaken inmates who change their personalities for the better by improving their religious knowledge in LPKA Class II Kendari. Skills training includes making hydroponics, making chairs from aqua bottles and trash, and making handicrafts such as ashtrays and bracelets. Skills development was done to develop the social spirit of correctional protege when they return to society and can also help to mingle with their surroundings. The implementation of correctional protege Mentorship at LPKA Class II Kendari which includes personality and independence mentoring has not been optimally carried out, it will have an unfavorable impact on correctional protege when reintegrating with a community that still has a negative stigma towards them.

\section{ACKNOWLEDGMENTS}

The author would like to thank Akbar Amnur, A.Md.IP, SH, M.Sc., as the Head of the Kendari Class II LPKA who has permitted the author both to write a dissertation at the UMI Makassar Postgraduate Program, as well as for writing scientific law journals.

\section{REFERENCES}

Al-Maidah, A. P., Muchtar, S., \& Mirzana, H. A. (2020). The Analysis of Prison Penalty for Children in Perspective on the Theory of the Purpose Punishment. International Journal of Multicultural and Multireligious Understanding, 7(5), 568-575.

Anonim. (2008). Cetak Biru Pelaksanaan Sistem Pemasyarakatan. Departemen Hukum dan HAM Direktorat Jenderal Pemasyarakatan bekerjasama dengan Kedutaan Besar Australia - The Asia Foundation - Institute for Criminal Justice Reform (ICJR).

Anonim. (2020). Home. Sistem Database Pemasyarakatan .

Aprilianda, N. dkk. (2014). Model Pembinaan Anak Berbasis Pendidikan Layak Anak Dalam Sistem Pemasyarakatan. In Laporan Akhir Pengkajian Hukum.

Arifai, A., Thalib, H., Husen, L. O., \& Ahmad, K. (2020). The Essence and Principles of Fostering Child Prisoners : Case Study of Prisons in Southeast Sulawesi Province. IOSR Journal of Humanities And Social Science (IOSR-JHSS), 25(12), 4557. https://doi.org/10.9790/0837-2512014557

Arifulloh, A., Prasetyo, T., \& Wahyuningsih, S. E. (2017). The Factors Affecting Recidivist Children Against The Children's Development of The Penitentiary System. International Journal of Business, Economics and Law, 13(4), 199-205.

Bukhori, B. (2016). Pengembangan Social Skill Narapidana Melalui Pelatihan Pijat. Dimas: Jurnal Pemikiran Agama Untuk Pemberdayaan, 16(1), 49-66. https://doi.org/10.21580/dms.2016.161.891 
Efendi, J., \& Ibrahim, J. (2018). Metode Penelitian Hukum: Normatif dan Empiris. Kencana Prenada Media Group.

Lumowa, H. B. (2017). Hak Pendidikan Bagi Narapidana Anak Ditinjau Dari Undang-Undang Nomor 35 Tahun 2014 Tentang Perlindungan Anak. Lex Privatum, 5(1), 137-145.

Moustafa, N. (2014). The Right To Free Exercise of Religion in Prisons: How Courts Should Determine Sincerity of Religious Belief Under RLUIPA. Michigan Journal of Race \& Law, 20(1), 213-244.

Mursyid, M. (2019). Implementation of Human Rights Protection Towards in Penitentiary of Children in Makassar. Substantive Justice: International Journal of Law, 2(1), 71-88.

Ningsih, S. M., Arsyad, M., \& Upe, A. (2020). Pola Pembinaan Narapidana Anak Laki-Laki Di Lembaga Pembinaan Khusus Anak (LPKA) Kelas II Kendari. Societal: Jurnal Pemikiran Dan Penelitian Sosiologi, 7(2), 111-121.

Ningtyas, E. S., Gani, A. Y. A., \& Sukanto. (2013). Pelaksanaan Program Pembinaan Narapidana Pada Lembaga Pemasyarakatan Dalam Rangka Pengembangan Sumber Daya Manusia (Studi pada Lembaga Pemasyarakatan Klas IA Lowokwaru Kota Malang) Erina. Jurnal Administrasi Publik (JAP), 1(6), 12661275.

Nugroho, H. (2017). Narcotics Prevention Among Prisoners By National Narcotics Agency (BNN). Jurnal Dinamika Hukum, 17(2), 158-162. https://doi.org/10.20884/1.jdh.2017.17.2.846

Pratiwi, C. S. (2019). Optimizing Restorative Justice Program for The Best Interest of The Children in Reforming Juvenile Justice System in Utah. Legality : Jurnal Ilmiah Hukum, 27(2), 242-258.

RA, M. S., Hamdika, Y., \& Al-Fatih, S. (2020). The Impact of COVID-19 Through the Lens of Islamic Law: An Indonesian Case. Lentera Hukum, 7(3), 267-278. https://doi.org/https://doi.org/10.19184/ejlh.v7i3.18983

Rezaliano, M. K. A., \& Humsona, R. (2018). Strategi Pembinaan Anak Didik Pemasyarakatan di Lembaga Pembinaan Khusus Anak (LPKA) Kutoarjo (Studi Kasus di Lembaga Pembinaan Khusus Anak Kutoarjo, Kabupaten Purworejo,. Journal of Development and Social Change, 1(1), 44-52.

Sitorus, C. N. D. (2018). Kajian tentang Pemberdayaan Pada Narapidana Perempuan Kasus Narkoba Di Rutan Kelas IIB Tanah Grogot. EJournal Sosiatri-Sosiologi, 6(4), 134-148.

Suwarnatha, I. N. N., \& Gorda, A. A. A. R. T. (2016). Restructuring of Protection Design of Child Prisoners of Correctional System to The Guidance System Humanisme. South East Asia Journal of Contemporary Business, Economics and Law, 10(4), 37-44.

Thalib, H., Rahman, S., \& Semendawai, A. H. (2017). The Role of Justice Collaborator in Uncovering Criminal Cases in Indonesia. Diponegoro Law Review, 2(1), 27. https://doi.org/10.14710/dilrev.2.1.2017.27-39

Thohir, M. M. bin. (2016). Metode Pembinaan Keagamaan yang Efektif Bagi Narapidana/Tahanan di Lembaga Pemasyarakatan Kelas II-B Lumajang. Dakwatuna: Jurnal Dakwah Dan Komunikasi Islam, 2(1), 13-33.

Tjahjati, E. (2012). Perlindungan Dan Pembinaan Terhadap Warga Binaan 
Pemasyarakatan (Wbp) ( Study Di Lembaga Pemasyarakatan Anak Klas IIA Blitar ). Mizan: Jurnal Imu Hukum, 1(2), 55-62.

Wulandari, S. (2012). Efektifitas Sistem Pembinaan Narapidana Di Lembaga Pemasyarakatan Terhadap Tujuan Pemidanaan. Hukum Dan Dinamika Masyarakat, 9(0854), 131-142. 